\title{
CORRESPONDENCE
}

\section{POSTAL SERVICE IN SOUTH GEORGIA}

The Polar Record for May 1956 publishes the full text of the Application by the Government of the United Kingdom to the International Court of Justice at the Hague on 4 May 1955 relative to the encroachments of the Government of Argentina in British Antarctic Territory. In para. 20 (i) it is stated that a post office was established at Grytviken in 1912 (Polar Record, Vol. 8, No. 53, 1956, p. 134). Actually this took place in 1909, for according to the Annual Colonial Report for that year "A post-office has been opened at South Georgia, and 1000 letters and 389 postcards were despatched to various countries by the mail which left on the 23rd December 1909". Mr J. I. Wilson, who had been appointed Stipendiary Magistrate at South Georgia from 20 November 1909, was the postmaster.

JAMES ANDREWS

23 KINCATH AVENUE,

BURNSIDE,

RUTHERGLEN

17 July 1956

\section{ANTARCTIC ICE TERMINOLOGY: "ICEBERG TONGUES"}

A "glacier tongue" is defined in the recent illustrated ice glossary (Polar Record, Vol. 8, No. 52, 1956, p. 6) as " an extension of a glacier projecting seaward and usually afloat". In general, such glacier tongues break up, a short distance out from the coast, into an accumulation of discrete icebergs which are usually aground and may or may not be connected by bay ice or fast ice.

In the Polar Record, Vol. 8, No. 52, 1956, p. 65, there is a discussion concerning the term "ice stream" first proposed in the Polar Record, Vol. 7, No. 48, 1954, p. 185 and p. 231. A term of this sort is much needed, and I am in favour of the term "Ice stream" which has been proposed.

When such an "ice stream" meets the coast it frequently produces a "glacier tongue". There are, however, many examples along the coast of Antarctica of tongues which occur with no glacier or ice stream behind them. The inland ice sheet sweeps down uniformly to the coast. At some places it breaks off at the coast to form icebergs which presumably are swept away if the water is deep, and the coast remains as an untramelled one of sheer, vertical ice cliffs. However, for no reason as yet advanced, the ice sheet in other places cracks up upon reaching the coast to form a number of discrete mounds of ice heavily crevassed, whose separations increase with their distances from the coast. For some distance out the spaces between these "icebergs" may be choked with fast ice and drift snow, but as the bergs become more dispersed further from the coast they are generally joined by thin fast ice.

I wish to propose the term "iceberg tongue" for such a feature which is not backed by a glacier or an ice stream. 
One possible reason for an "iceberg tongue" is a series of low rocky hills at the coast (similar to the Vestfold Hills or Hordern Hills in the Australian sector) over which the ice sheet rides and cracks asunder. A shallow bank at sea beyond the coast is then needed to ground the icebergs produced and prevent them from drifting away.

I should perhaps mention that there is a distinction between an "iceberg tongue" and an "iceberg bank". The latter term has been used in Greenland for an accumulation of icebergs grounded on a shallow bank at sea. The term has not found use in Antarctica for it is generally assumed that around the antarctic coast any "bank" will be studded with grounded bergs. Thus, in our present region of activity, the Fram Bank and the Four Ladies Bank are regions of iceberg accumulation. Such iceberg banks need not, however, be connected to the coast and in general are not.

An iceberg tongue on the other hand is (like a glacier tongue) an extension of the continental ice sheet out into the sea.

P. G. LAW

ANTARCTIC DIVISION,

DEPARTMENT OF EXTERNAL AFFAIRS,

187 COLLINS STREET,

MELBOURNe, C. 1

31 July 1956 


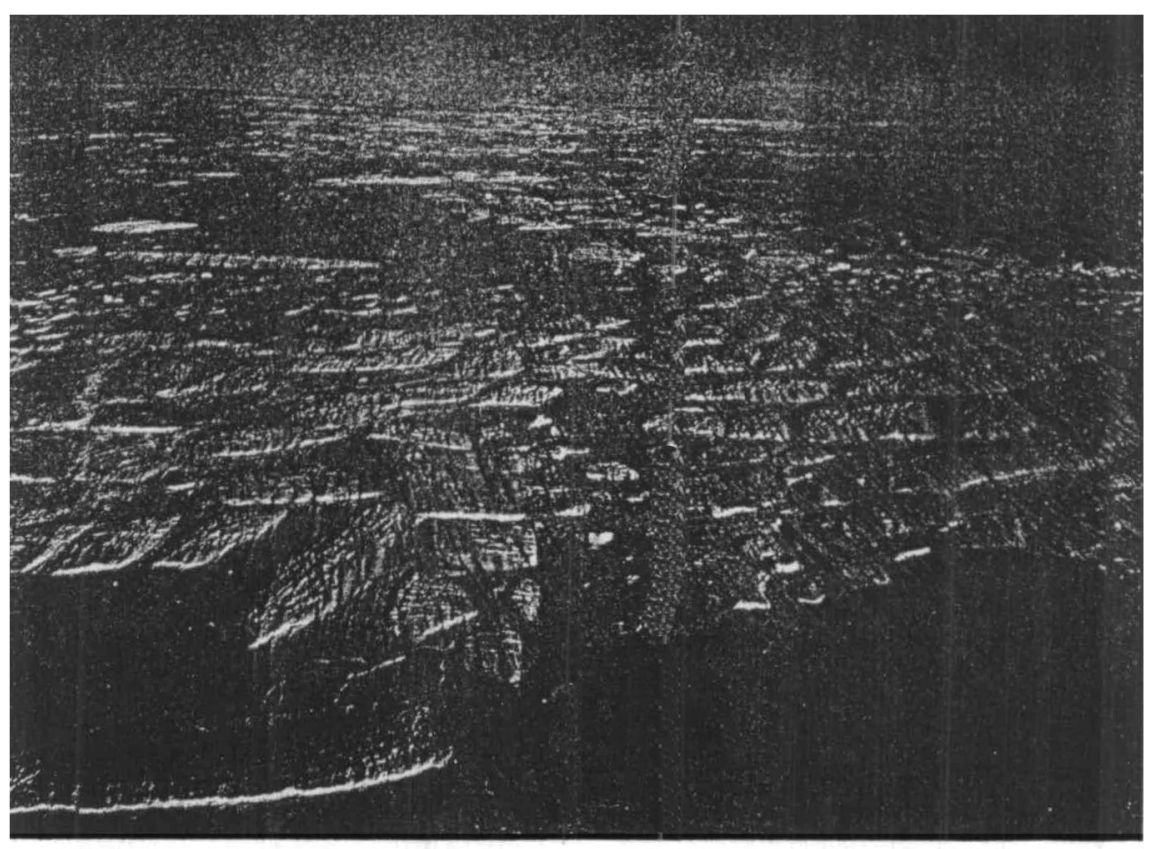

Iceberg tongue at eastern limit of Davis Bay. The icebergs extend into open water to the left of the photograph

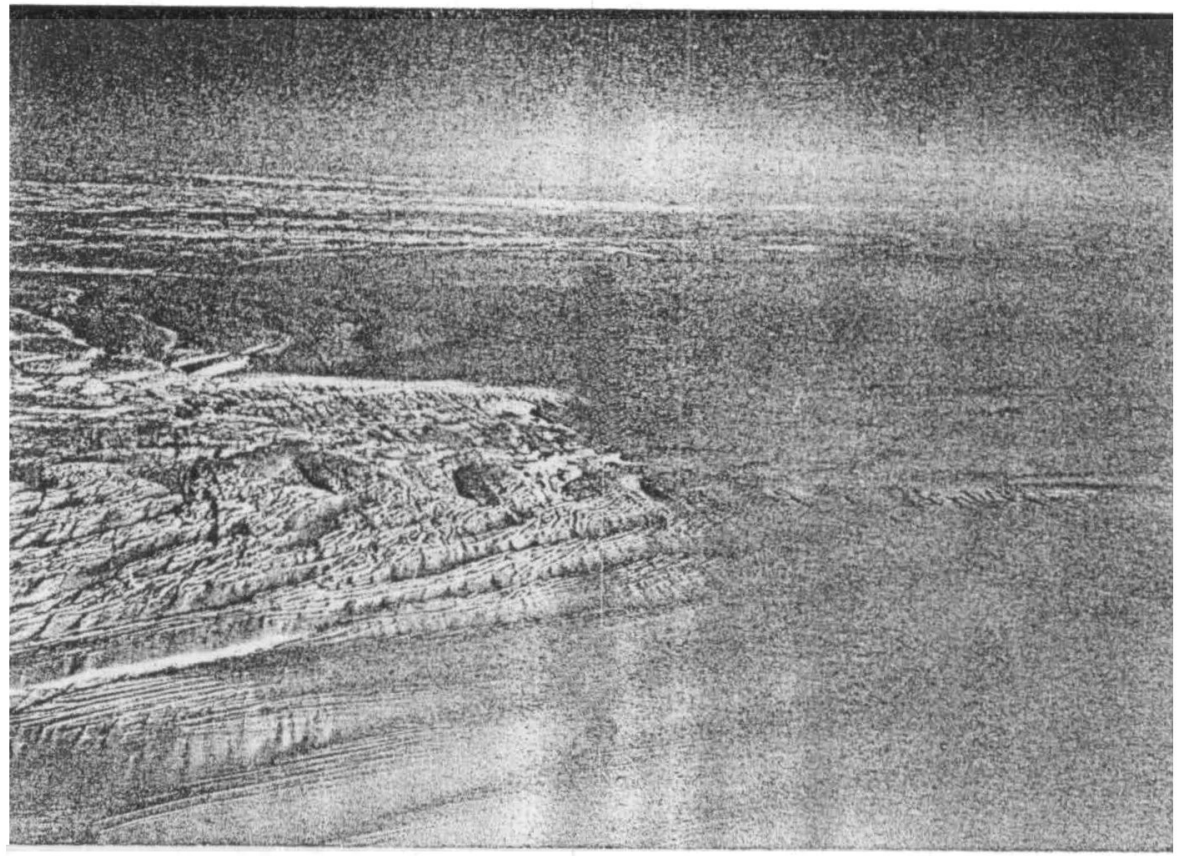

Beginning of iceberg tongue. Note that there is no defined glacier or ice stream

Photographs A.N.A.R.E.

(Fucing p. 376) 